Nebojša Pavlović ${ }^{1}$

University Kragujevac,

Faculty of Management and Tourism, Vrnjačka Banja
SCIENTIFIC REVIEW ARTICLE doi:10.5937/ekonomika1602085P

Received: March 30, 2016

Accepted: May 9, 2016

\title{
EVALUATION OF TEACHERS' WORK IN HIGH EDUCATION INSTITUTIONS OF SERBIA
}

\begin{abstract}
Evaluation of teachers' work is faced with critics by teachers and students. It is a common impression that evaluation of teachers'work at faculties is not a good process.

The aim of this research is to use responses from the questionnaire developed for this purpose in order to determine the quality of evaluation of teachers' work procedure at faculties. There was an effort to develop a model which would response regarding the quality of evaluation process at faculties. Data used for development of model were collected via Google Forms, where 427 teachers from all universities in Serbia were involved.

Research results indicated that presented model is able to differ approval and disapproval of evaluation work procedures at faculties.

Obtained model encouraged clear and scientific explanation of evaluation of teachers' work. Further researches should include variables which can be effective for further development of a model.
\end{abstract}

Keywords: evaluation of teachers, faculty, teacher, student, model

JEL classification: A20,C63,I21

\section{ВРЕДНОВАЊЕ РАДА НАСТАВНИКА У ВИСОКОШКОЛСКИМ ИНСТИТУЦИЈАМА СРБИЈЕ}

\section{Апстракт}

Евалуација наставниковог рада је на удару критике и наставника и студената. Општи је утисак да вредновање рада наставника на факултетима није добро.

Циљ истраживања је био да на основу одговора на питања из конструисаног упитника за потребе овог истраживања, откријемо квалитет процедуре вредноваьа рада наставника на факултетима. Покушали смо да направимо модел који би одговорио на питање када је процесс евалуације на факултетима добар а када не. Подаџи који су коришћени за прављење модела су прикупљени анкетом преко Google Forms-a, где је учестовало 427 наставника са свих универзитета у Србији.

Из резултата истражсиваға је закључено да постваљени модел може да разликује одобравање и неодобравање прочедура вредновањ а рада на факултетима.

\footnotetext{
${ }^{1}$ racapn@gmail.com
} 
Добијени модел помаже јасном и научном објашњењу евалуащије рада наставника. У следећим истраживањима потребно је увести варијабле које могу да утичу на даље усавриавање модела.

Кьууче речи: евалуачија рада наставника, факултет, наставник, студент, модел

\section{Introduction}

Bologna process in the high education of Serbia has officially started in 2003. It can be assumed that the period of 13 years was a long period during which everything came in its place and the system became capable of work without great problems and turbulences. However, practices have shown that situation is not that perfect. This reform process as good (and right) solution for high education is still faced with problems for which was supposed to be solved in the previous period.

One of such unsolved problems is an evaluation of teachers' work in high education institutions. Bologna process noted it as Evaluation of teachers' work (Bologna declaration, 2003). This research subject - Evaluation of work was defined as a process by which something is measured by comparing with defined standards and criteria (Pavlovic, 2015). The measurement was conducted in order to provide data on quality of teachers' work (Act on students' evaluation of pedagogical work of teachers, 2006). This information was supposed to be used for corrections of their work. It was supposed to use evaluation for "more objective" HR solutions at faculties through side effects.

Therefore, it can be concluded that there is nothing more to add to the evaluation process. There are criteria and standards according to which teachers can be evaluated. Students are determined as evaluators of teachers' work. Where does the problem appear?

Creators of evaluation plan wanted to shift evaluation from economy directly to education institutions. It was planned to have students as clients who could express their satisfaction or dissatisfaction by evaluating of teachers' work. However, the practice indicated on numerous questions. One of the first questions was related to the competency of students to make an appropriate evaluation of teachers. Also, there was a question on the purpose of the evaluation itself. Is it conducted in order to provide information which could be helpful for correction of teachers' work or they can be used for control of their work? The latter option implies the option for them to have a direct impact on carrier and development of teachers' work in high education institutions.

No precise or correct answer has been obtained so far. The relative closeness of faculties impacted on the lack of application of good practices in other education institutions. Therefore, numerous critics by students and teachers appeared. The greatest problem was the absence of evaluation process model, a model of good (or bad) teacher. It leads to the absence of criteria and standards for evaluation of teachers' work at faculties. The interesting fact was that there was no great interest in finding the best solution for teachers' evaluation during the previous period. Teachers and students were accustomed to such condition. Teachers adapted their work to students' "needs" in situations where problems could appear. It is simple action like at the market. 
The research problem was related to the process of evaluation at our faculties. According to the assumption that evaluation process at high education institutions in Serbia is not good enough, the question appeared: What can effect on the teacher to claim that evaluation process of his work is good or not?

The aim of the research was use following variables: "corrective measures for teachers with bad results of the evaluation, evaluation of students' competencies for evaluation of teachers' work and scope of evaluation" in order to determine the influence on the estimation of evaluation procedure of teachers' at faculties. Regarding that, the model which should be used for obtaining responses to the problem of research work was developed.

Using the random sample, 427 teachers from universities in Serbia participated in this research. The great number of them indicated the actuality of problem-related to the evaluation of teachers' work. Obviously, it is an existing problem which is unwillingly mentioned. Also, a very small number of research works on this subject implied the conclusion that people from universities have a lack of will to speak about this.

Modeling method was used for this work. The main characteristic of this method are unity and connection between theory and practice. Modeling method is research process for generating of character system. Also, this model can replace the real form and it can be helpful in using of simulation for research and transfer of findings into real form.

Limitations of modeling method is also limitations of this research. The model can be only relatively adequate to the original. Otherwise, it would not be known as a model. Also, the model is inevitable simplifying of researched form. It represents abstraction, a certain realization of the original. The model method includes significant limitations since findings are based on analogy category or similarity.

The purpose of this research is to place a model with which the answer to this question can be provided: What has an effect on the attitude of teachers that evaluation is good or not.

This research provided results which showed that model is able to differentiate approval and disapproval of procedures for evaluation of teachers' work at faculties. Regarding future evaluation processes, it is important to provide researches in multiple directions. The reason for that lies in a fact that evaluation is not uniform and it includes research on many indicators. This would provide more information helpful for a correct evaluation of teachers' work at faculties.

\section{Literature review (Theoretical frame)}

Evaluation of teachers' work is not a new idea. It started to develop during the second half of $20^{\text {th }}$ century. However, evaluation was followed by failures due to bad communication between those who evaluate teachers' work, those who implement this and teachers themselves who were in the focus of evaluation. At the beginning, there was the greatest gap between education authorities who started evaluation and teachers whose work was evaluated. The confusion in teachers developed for no real and known reason related to the evaluation process. Teachers were asked if that is a review of their work in order to create the best model of teachers' work or standardization of their work in order to improve a quality of work at faculties (Beck et al, 2002). 
Some of many questions by teachers were: What to do after the evaluation? Is there a need for corrective measures for teachers with bad results? What should be developed for teachers with excellent results? Unfortunately, the situation with evaluation of teachers in high education institutions did not change to date. There are no sufficient mechanisms and agreed procedures for evaluation of teachers' work (Marsh, 2006). Such task is dedicated to a small number of people from faculties. There is an impression that they do this job only because they have the obligation for that.

The paradox is that evaluation is better and more seriously accepted in primary and secondary schools rather than in faculties (Maksić, 2006). These schools included evaluators trained through many pieces of training and programs in order to make evaluation processes in a better way. The confusional information was that only students observe teachers' work beside mandatory of evaluation. Such way of the evaluation was faced with resistance in teachers and two questions appeared: Is evaluation as such reasonable and should it exist in such form? If it is needed, what would be the way of improving and optimizing of the evaluation process?

Many recognized professors were against evaluation of teachers' work in a way demanded by Bologna reform. Professor Lisseman was one of loudest in this case. Also, he is known as a bitter opponent of Bologna reform. His disagreement with education reforms started with critics on quantitative measurement in education (Lisseman, 2009). He claimed that it is not possible to measure everything using numbers. Also, it is not possible to measure the quality of teachers' work in this way. He was highly against the model of a teacher who is in obligation to publish his/her works for prestige journals and in certain time periods, which is logical. Also, he did not like the idea that teacher should be mobile in order to develop himself/herself as more quality teacher ready for improvement. He mentioned Immanuel Kant, one of the famous philosophers of all times, who was not mobile since he never left his hometown Kinizburg during his life. Also, according to this model, Kant would not achieve progress in his carrier since he did not publish anything for 10 years before writing a book "Critique of Practical Reason", one of biggest works in the history of philosophy. The rule to use exclusively quantitative indicators was obviously unsuccessful at a time. Beside statistic data, it is important to include other indicators for quality of teachers' work. These indicators would be used for better, wider and more quality description of teachers' work.

The quantitative approach in evaluation presented achievement of imagined goal regarding defined criteria. It looked like this in practice: achievements were compared with defined goals using instruments for evaluation of teachers' work designed for this occasion (Green \& McClintok, 1991). The main problem with the quantitative approach is the way how data are collected. Doubt in a good way of data collection led to doubt in the validity of results obtained in this way. It is easy to view consequences of such evaluation (Murray, 1987). What should be done with these results? What actions should be conducted in order to correct teachers' work if measurement does not present the real situation?

During the review of literature in the area of evaluation of teachers' work, it is not favorable to acknowledge that interest of researchers in these issues is very lowered during last decade. There are almost no progressive steps in solving problems related to the evaluation of teachers' work. It is an exceptional case where one topic is so interesting and controversial and yet, it is not enough researched (Marsh, 2006). 
The special problem is how to use feedback information for improvement of teachers' work. Results of evaluation should be used for correction of teachers' work. Instead of highlighting of teaching efficiency, it is important to focus on HR solutions (Marsh, 2006). HR solutions can be used as a good replacement for a teacher with weaker results. Also, these solutions are often expensive. Using this approach teachers found themselves to be endangered. It is one of the important reasons why they started to criticize evaluation of their work.

Inadequate evaluation lacked the opportunity to take actions for improvement teachers' work in a low-cost way. University teachers are not sufficiently pedagogically trained for good teachers. Feedback information obtained by evaluation should be priceless for them. Beside that, outside help for them would be useful so this information could be applied in practice. Questions for emergent responses are related to a development of a program for promotion of teachers' work. Also, there is a question: Why there are no more researches useful for all parties in this area?

As it can be assumpted, there is no simple system for evaluation of teachers' work. Therefore, there is no such system for evaluation of teaching at the faculty. However, it is possible to include more evaluation models which can be used for evaluation of teachers' work in a reliable way. More methods would include more data resources. The first step would be aimed at the development of an own model of evaluation. Each faculty, each subject and, therefore, each teacher should include certain specifics which need to be adopted during evaluation of teachers' work. It is not the same to evaluate work of a teacher of mathematics and teacher of musical education. Also, classes in Forensic sciences are not interesting in the same way as classes in Biology. Each teacher has a different organization of his/her classes so it should be also observed and imported into the model. It is especially important to include teachers in the construction of instruments for evaluation of their work. That is the way for avoiding of discrimination of certain individuals with bad results only because their subject is not interesting for students' evaluation in a proper manner.

Evaluation is focused only on the quality of teaching at faculty, in the classroom (Hunt, 2013). However, teaching is a wider term and it included many actions conducted within and out of the classroom. Evaluation should also include the development of teaching program, new courses with students, creative mentorship of teacher, help in the development of works and dissertations, consultancies one-on-one and students advising, sharing experience in area of research techniques, use of technologies and software in learning, works, researches, positive teachings and many more.

It is not easy to answer which data sources are suitable for evaluation. Information from students and colleagues are important including data are given by teachers themselves. Students are the most important data source. Also, they are able to evaluate how a teacher is prepared for teaching, does he/she motivates students and respect them. Numerous researches showed that students are capable and reliable for evaluation of teachers (Marsh, 2006).

Beside active students, many faculties asked their former students to evaluate teachers' work. It was acceptable for many reasons. One of the most important reasons is that former students are not concerned by consequences in case of lower grades for teachers. Other reasons can originate from greater experience of former students. Researches showed that evaluations of former students are always nearly matched with evaluations of current students (Marsh, 2006). 
Colleagues teachers can also be data sources beside students (Braskamp at al., 1984). Such kind of evaluation is not often proposed at faculties although it should have more important position during evaluation of teachers' work. Colleagues teachers could provide very valuable data on teaching in a classroom. This way of evaluation is not difficult and it is considered as feasible. The teacher should visit teaching classes of his/her colleague and make correct report according to his/her perception, knowledge and experience. It could be helpful for making of feedback information to teachers in order to improve their work but also to faculty administration in order to make correct decisions in HR domain. Beside visiting classrooms, teachers-colleagues could review teaching material used on classes and follow teacher's contribution to the development of teaching programs, books preparations, writing articles, etc. Students are not capable of evaluating a teacher in these specific areas. On the other hand, teachers mostly complained that their work in these areas is not evaluated.

Each teacher should have his/her own portfolio including data with information needed for evaluation of their work (Edgerton at al., 1991). There is a small number of faculties which insist on this data sources for evaluation of their work. Also, few faculties insist on such kind of data in order to evaluate teachers. Portfolio usually includes teacher's references related to the publishing of works and books which are not enough. The portfolio should include teacher's plans for progress, his/her efforts in teaching improvement and future teaching objectives. Also, a teacher can express his/her expectations regarding teaching and researches, his/her plans for improvement of his/her pedagogical competencies.

Marsh (2007) claimed that evaluations of teachers' work made by students are multidimensional, reliable, stable and they relatively present the real way of efficiency and effectiveness of teaching. Students' grades are considered as useful for promotion of teaching efficiency if they are correlated with suitable consultancies after evaluation. Corrections on teachers' work are an important part of evaluation process.

There are not many research works on this subject in Serbia. During the second half of 20th century, evaluation of teachers' work was unilateral. There were usual responses on the question what should be used as a subject of evaluation (Potkonjak, 1972). Mandic and Vilotijevic (1980) and Vilotijevic(1992) made researches on pedagogical in the school. All of these works are usually connected with teachers from primary and secondary schools. Work by Jankovic and Jaric (2009) within qualitative research clearly explained some processes of evaluation. Statements of teachers on the evaluation of their work were especially interesting. All teachers claimed that evaluation is extremely important and that is good to provide an evaluation of teachers' work. However, all teachers also insist on being careful regarding results from an evaluation of their work by students. Teachers think that students cannot evaluate teachers' work in the best way. It is interesting to know that teachers want to be actively involved in the evaluation process, especially during questionnaire development.

\section{Methodology}

Research is quantitative and it is aimed to the investigation of the impact of a subject who conducts the evaluation, application of corrective measures for teachers with 
lower results, evaluations of students' competencies for evaluation of teachers' work and scope of the evaluation, estimation of evaluation procedure for faculty professors. The questionnaire was developed for the purpose of this research.

\section{Methods of modeling}

Graphics 1: Basic cognitive models and modeling

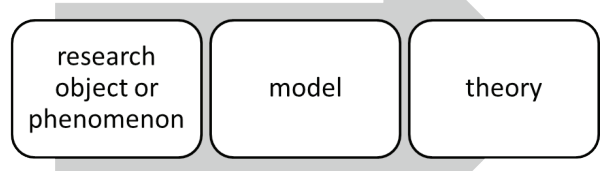

Source: Graphics created made by the author

\section{Respondents}

The research included 427 faculty professors. The sample contained $242(57 \%)$ male respondents and $185(43 \%)$ female respondents. Also, it included $106(25 \%)$ regular professors, $76(18 \%)$ associate professors, $136(32 \%)$ docents and $109(25 \%)$ cooperatives in teaching and assistants. The domain of natural sciences included 63 $(15 \%)$ respondents, $168(39 \%)$ respondents from the domain of social sciences and 196 $(46 \%)$ respondents from the domain of technical sciences.

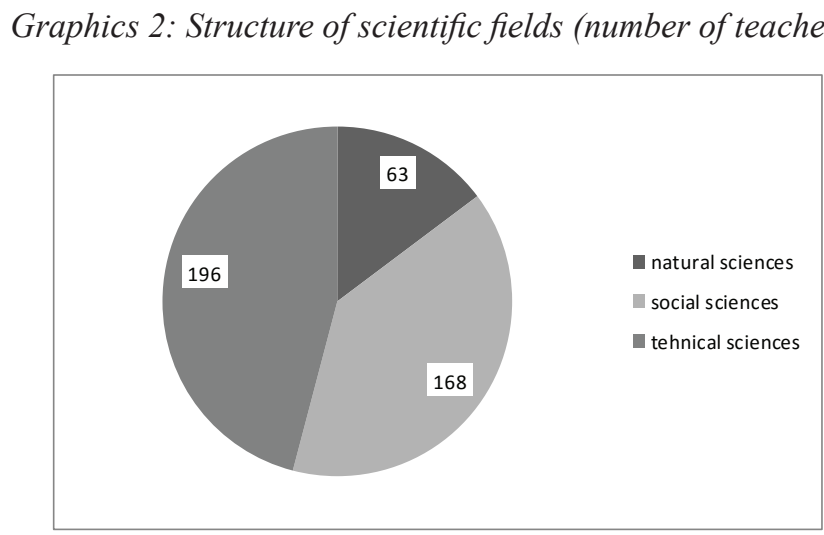

Source: Data from the research of the author 
Graphics 3: Structure of teachers who participated in the survey (number of teachers)

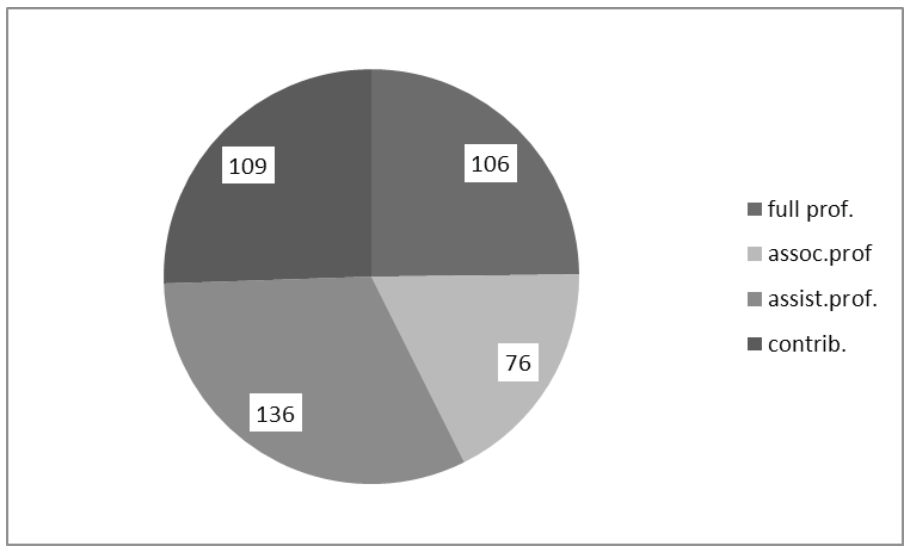

Source: Data from the research of the author

\section{Research instrument}

For purposes of this research, a questionnaire of 8 questions was developed. All questions are closed including the possibility of choosing one answer. Subject variable related to evaluation is operationalized through the question: "Which evaluation of teacher's work is present in your faculty?" Offered responses were: evaluation by students and evaluation by colleagues-teachers or self-evaluation and non-evaluation of teachers' work at our faculty. Application of corrective measures for teachers with low results of evaluation is operationalized through questions: "Are there any corrective measures for teachers with low evaluation results?". The estimation of students' competency for evaluation of teachers' work is operationalized by the question: "According to your opinion, are students competent to evaluate teachers' work?" The scope of the evaluation is operationalized through the question: "Are all teachers included in the evaluation of teachers' work?" Offered responses for these three questions were following: Yes; No and I don't know. Assesment of evaluation procedure is operationalized through the question: "Do you think that the work evaluation of teacher from your faculty is good enough?" while offered answers were: Yes and No.

Questions related to gender and occupation of respondents and subject domain were not used in the analysis.

\section{Procedure}

The questionnaire was developed in electronic form and placed on website Google Forms where it was available during next 30 days. Survey respondents were emailed on the availability of questionnaire and asked to offer their answers. Answers were taken from Google in electronic form (in the form of an electronic table). All respondents participated anonymously and on a voluntary basis. 


\section{Data analysis}

Direct, binomial logistic regression, was used for testing of the effect of evaluation subject, application of corrective measures for teachers with low results, competency assessment of students for evaluation of teachers' work and scope of assessment and assessment of evaluation procedure for faculty professors' work. Criteria variable as four question is dichotomous where answers No and I don't know are marked with 0 , answer Yes was marked with 1 . Assumptions on multicollinearity and presence of extreme values in data were reviewed. During analysis of extreme values, 7 cases with values $\mathrm{z}>2,5$ were excluded from the analysis. The assumption on the absence of multicollinearity between predictor variables and size of the sample were satisfied.

\section{Results}

A complete model which included all predictor variables is statistically important $(\chi 2(7)=108.06 \mathrm{p}=0,00)$. It implied that model can differ approval and disapproval of evaluation of faculty professors' work. The entire model explained between $22.7 \%$ (Cox and Snell R2) and 33.3\% (Nagelkerke R2) variances at dependent variable.

Model exactly differs $78.3 \%$ of cases. The correctly classified percentage of $90,4 \%$ cases were classified for answers No and I don't know on the 4th question while 44\% cases were classified for answer Yes.

According to the table below, application of corrective measures for teachers with low results of the evaluation (5th question in the survey) and assessment of students' competencies for evaluation of teachers' work (8th question in the survey) are statistically important for the model.

Table 1: The results of modeling

\begin{tabular}{|c|c|c|c|c|c|c|c|c|}
\hline & $\mathrm{D}$ & $S_{5}$ & W & ff & Si & OD & \multicolumn{2}{|c|}{$95 \%$ interval of trust } \\
\hline & B & S.E. & Wald & df & Sig. & OR & level & level \\
\hline $5^{\text {th }}$ question, answer YES & $-2,194$ & ,330 & 44,313 & 1 &, 000 &, 111 &, 058 & ,213 \\
\hline $5^{\text {th }}$ question, answer NO & $-1,419$ &, 320 & 19,613 & 1 &, 000 &, 242 &, 129 & ,453 \\
\hline $8^{\text {th }}$ question, answer YES & $-2,390$ & ,410 & 34,026 & 1 & 000 &, 092 &, 041 & ,205 \\
\hline $8^{\text {th }}$ question, answer NO &,- 666 & ,366 & 3,309 & 1 &, 069 &, 514 &, 251 & 1,053 \\
\hline $10^{\text {th }}$ question, answer YES & 1,015 &, 574 & 3,125 & 1 & 077 & 2,760 &, 896 & 8,505 \\
\hline $10^{\text {th }}$, answer NO &,- 592 & ,440 & 1,816 & 1 & ,178 &, 553 &, 234 & 1,309 \\
\hline $1^{\text {st }}$ question &, 564 & ,447 & 1,587 & 1 & ,208 & 1,757 &, 731 & 4,222 \\
\hline Constant & ,226 &, 545 & ,173 & 1 & ,678 & 1,254 & & \\
\hline
\end{tabular}

Source: This table is taken from survey data(SPSS)

\section{Discussion}

If during answering on 5th question (Are there any corrective measures for teachers with low results?) respondent shifts from answer "Yes" to answer "No", the chance to answer the 4th question (Do you consider evaluation at your faculty as good?) 
from "No" and "I don't know" to "Yes" is decreased for 0,11 times. Using trust interval in the value of $95 \%$, it can be claimed that chance for answering the 4th question is between 0,06 and 0,23 .

If during answering the 5th question (Are there any corrective measures for teachers with low results?) the respondent shifts from answer "No" to answer "I don't know", the chance to answer 4th question (Do you consider evaluation at your faculty as good?) instead "No" and "I don't know" to "Yes" is decreased for 0,24 times. With an interval of trust in the value of $95 \%$, it can be claimed that chance for answering the 4 th question is between 0,13 and 0,45 .

Overal and Marsh (1987) claimed in their researches that corrective measures conducted after evaluation are very useful for teachers and students. They conducted research on the same group of students in order to review differences. Students had much better results with teachers who were faced with corrections of their work after evaluation.

However, it doesn't have to mean that feedback information is going to have a corrective effect on teachers. McKeachie (1997) claimed that teachers can ask students to change. Also, teachers can undertake measures to students who make lower grades which will endanger good teaching (Murray, 1987). It is a big mistake to use evaluation for solving of HR issues and not for improvement and correction of teachers' work (Cashin, 1988; Wilson, 1986). Also, teachers often have a lack of knowledge in the area of pedagogy and didactic so feedback information is not helpful for them (Meyer, 2001). They need additional help (Marsh, 2007).

If during answering on 8th question (Do you consider students competent for evaluation of teachers' work?) respondent shifts from "Yes" to "No", the chance to answer the 4th question (Do you consider evaluation at your faculty as good?) from answers "No" and "I don't know" to answer "Yes" is decreasing for 0,09 times. With an interval of trust in the value of $95 \%$, the chance to answer the 4th question is moving between 0,04 and 0,20 .

Similar to these findings on students' competencies are claims by Marsh (2007) and Feldman (1987). They noted that students are able to differ different components of the efficiency of teachers' work. Also, researches claimed that students are not able to evaluate teachers' work through multidimensional evaluation. In that case, evaluation provides low results (Marsh and Groves, 1987).

\section{Conclusion}

Although model presents knowledge according to analogy category, the comparison with previous researches provided opinions that model had successfully replaced the research subject of this paper.

Modeling method provided knowledge that two variables have an effect on forming a model of teachers' opinions on an evaluation of their work. These variables are following: application of corrective measures for teachers with low results and estimation of students' competencies to evaluate teachers' work.

It can be concluded that evaluation of faculty teachers' work is going to be good if there are corrective measures for teachers with low evaluation results. Also, it can be 
claimed that evaluation of teachers' work will be good if students are competent enough to evaluate and estimate teachers' work.

\section{References}

Beck ,C., Hart, D. \& Kosnik, C. (2002). The Teaching Standards Movement and Current Teaching Practices, In Canadian Journal of Education, 27 (2-3): 175-194.

Bologna Declaration (2003). Fom http://www.ehea.info / Retrieved March, 12, 2016

Braskamp, LC.; Brandenburg, DC.; \& Ory, JC. (1984). Evaluating teaching effectiveness: A practical guide. Beverly Hills, CA: Sage.

Cashin, W. E. (1988). Student Ratings of Teaching. A Summary of Research. (IDEA paper No. 20). Kansas State University, Division of Continuing Education. (ERIC Document Reproduction Service No. ED 302 567).

Edgerton, R., Hutchings,P. \& Quinlan, K. (1991). The teaching portfolio: Capturing the scholarship in teaching. Washington, DC: American Association for Higher Education

Feldman, K. A. (1997). Identifying exemplary teachers and teaching: Evidence from student ratings. In R. P. Perry \& J. C. Smart, (Eds.), Effective Teaching in Higher Education: Research and Practice. Agathon, New York, pp. 368-395.

Green, J. C., McClintock, C. (1991), „The Evolution of Evaluation Methodology“, in Theory into Practice, Educational Evaluation: An Evolving Field, 30 (1): 13-21.

Hunt, L. (2013). University Teching in Focus:A learning-Centred Approach, Routledge, USA

Janković, A., Jarić, I. (2009). Uslovi rada nastavnog osoblja na univeritetu u Beogradu: Evaluacija rada nastavnika, Filozofija I društvo, Vol3/2009, Beograd

Knežević,M., Veselinović, P. (2015). New education policy’s priorities as a function of economic development of Serbia, Ekonomika, Vol1/2015, 151-167

Lisseman, K.P.(2009). Teorija neobrazovanosti - zablude društva znanja, Jesenski i Turk, Zagreb

Maksić, S., (2006). Podsticanje kreativnosti u školi, IPI Beograd

Mandić, P. - Vilotijević, M., 1980: Vrednovanje rada u školi, Sarajevo: Svjetlost

Marsh, H. W. (2007). Students'evaluations of university teaching: A multidimensional perspective. In R. P. Perry \& J C. Smart (Ed.), The Scholarship of Teaching and Learning in Higher Education: An Evidence-Based Perspective (pp.319-384). New York: Springer.

Marsh, H. W., \& Groves, M. A. (1987). Students' evaluations of teaching effectiveness and implicit theories: A critique of Cadwell and Jenkins. Journal of Educational Psychology, 79, 483-489

Marsh, WH (2006), Students Evaluations of University Teching:Dimensionality, Reliability, Validity, Potential Biases and Usefulness,htpp/ www.gvsu.edu/.../ marsh_2007_students_evaluati. 
McKeachie, W. J. (1997). Student Ratings: The Validity of Use. American Psychologist, $52,1218-25$.

Meyer, H., (2001). Didaktika razredne kvake, Educa, Nakladno društvo, Zagreb

Mihailović, B., Cvijanović,D, Simonović.Z.(2015). Role of business ethics in management of human resources, Ekonomika, Vol1/2015, 85-97

Murray, H. G. (April, 1987). Impact of student instructions ratings on quality of teaching in higher education. Paper presented at the 1987 Annual Meeting of the American Educational Research Association, Washington, DC. (ERIC Document Reproduction Service No. ED 284 495).

Overall, J. U., \& Marsh, H. W. (1979). Midterm feedback from students: Its relationship to instructional improvement and students' cognitive and affective outcomes. Journal of Educational Psychology, 71, 856-865.

Pavlović, N., (2015). Nove uloge menadžmenta ljudskih resursa, Djura Jakšić, Rača

Potkonjak, N. (1972). Vrednovanje rada u osnovnoj školi, Beograd: Jugoslovenski zavod za prouèavanje školskih i prosvetnih pitanja

Pravilnik o studentskoj evaluaciji studija pedagoškog rada nastavnika, (2006). UNS, Novi Sad, Retrieved March, 12, 2016, from www2.uns.ac.rs/sr/statut/pravilnici/ studentska Evaluacija.pdf

Vilotijević, M., (1992). Vrednovanje pedagoškog rada u školi, Beograd: Naučna knjiga.

Wilson, R. C. (1986). Improving faculty teaching: Effective use of student evaluations and consultants. Journal of Higher Education, 57, 196-211. 